\title{
Awl Nematodes, Dolichodorus spp. Cobb, 1914 (Nematoda: Secernentea: Tylenchida: Tylenchina: Dolichodoridae: Dolichodorinae) ${ }^{1}$
}

W. T. Crow and A. S. Brammer ${ }^{2}$

\section{Introduction and Distribution}

Awl nematodes were first described in 1914 from specimens collected at Silver Springs, Florida, and Douglas Lake, Michigan. Species of

Dolichodorus are found worldwide, but two species, D. heterocephalus and D. miradvulvus, are the most common in Florida. Usually, awl nematodes are found in moist to wet soil, low areas of fields, and near irrigation ditches and other bodies of fresh water. Because these nematodes prefer moist to wet soils they rarely occur in agricultural fields and are not as well studied as many other plant-parasitic nematodes.

\section{Importance}

Awl nematodes can cause damage as severe as that caused by the sting nematode (Belonolaimus longicaudatus), but because they are generally limited to moist habitats this damage is not as widespread. Awl nematodes have been shown to cause root stunting or reduced yields in many crops including carrots, celery, corn, cotton, beans, cabbage, lettuce, pepper, potato, spearmint and tomato. In addition they are known to cause damage to some ornamental plants such as impatiens, aquarium plants and turfgrasses.

\section{Life Cycle and Biology}

Adult awl nematodes range in length from about $1.5 \mathrm{~mm}$ to $3 \mathrm{~mm}$, making them one of the largest plant-parasitic nematodes. Both sexes are present throughout the life cycle. Eggs hatch after 14 to 17 days. Adults and all juvenile stages feed on roots, sometimes remaining in one spot for up to a week. Awl nematodes can survive in a fallowed greenhouse pot for up to three months.

An ectoparasite, awl nematode feeds on small or large roots, root tips and the hypocotyl. Twelve hours after inoculation, it feeds near the root tip. The cells there become brownish-yellow after several days, and brown lesions form. The result is tissue disorganization, root curvature and dead or dying root tips.

\footnotetext{
1. This document is EENY-241, one of a series of Featured Creatures from the Entomology and Nematology Department, Florida Cooperative Extension Service, Institute of Food and Agricultural Sciences, University of Florida. Published: September 2001. This document is also available on Featured Creatures Website at http://creatures.ifas.ufl.edu. Please visit the EDIS Website at http://edis.ifas.ufl.edu. Additional information on these organisms, including many color photographs, is available at the Entomology and Nematology Department website at http://entnemdept.ifas.ufl.edu/.

2. W. T. Crow and A. S. Brammer, Entomology and Nematology Department, University of Florida, Gainesville, FL.
} 


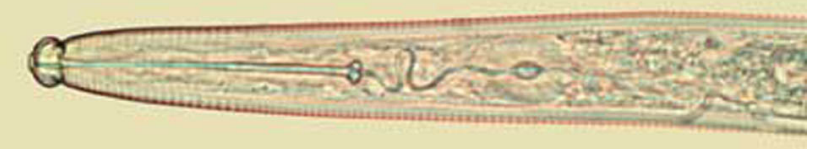

Figure 1. The head of an awl nematode in the genus Dolichodorus. Credits: Jon Eisenback, Virginia Polytechnic Institute and State University

\section{Symptoms}

The damage caused by awl nematodes leads to severe stunting of the entire plant because of depletion of the root system. The roots are often coarse with stubby tips. The few secondary roots that remain are stubby as well.

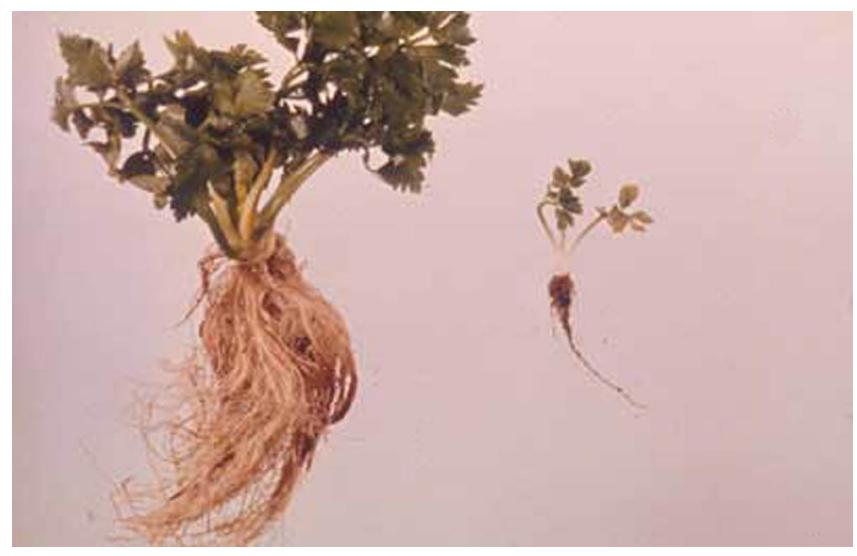

Figure 2. Awl nematodes (Dolichodorus spp.) cause severe stunting, which can be seen in the celery plant on the right. The plant on the left is unaffected. Credits: Division of Plant Industry

\section{Hosts}

Hosts include anubius, balsam, bean, Bermudagrass, cabbage, carnation, celery, centipedegrass, corn, cotton, cranberry, hydrilla, impatiens, St. Augustinegrass, sugarcane, tomato, palms, pepper, potato and water chestnut.

\section{Management}

Often awl nematodes are an indicator of excess soil moisture. In some cases improving drainage or reducing irrigation may reduce or eliminate problems with this nematode. Using soil dredged from ditches, ponds or other water sources to top-dress agricultural fields or to make planting beds may be a source of contamination with awl nematodes. When awl nematodes are present in high numbers this practice should be avoided.

For the most current recommendations for nematode management on a particular crop see the Nematode Management Guide.

\section{Selected References}

Christie, J.R. 1959. Plant nematodes, their bionomics and control. Univ. of Fla. Agric. Exp. Sta., 216 pp.

\section{Orton Williams, K.J. 1986. Dolichodorus} heterocephalus. C.I.H. Descriptions of Plant-parasitic Nematodes. Set 4, No. 56. Commonwealth Institute of Parasitology. C.A.B. International. 3 pp.

Paracer, S.M. 1968. The biology and pathogenicity of the awl nematode, Dolichodorus heterocephalus. Nematologica. 13:517-524.

Perry, V.G. 1953. The awl nematode, Dolichodorus heterocephalus, a devastating plant parasite. Proc. Helminthol. Soc. Wash. 20:21-27.

Smart, G.C. and N.B. Khoung. 1985. Dolichodorus miradvulvus n. sp. (Nematoda: Tylenchida) with a key to species. Journal of Nematology 17:29-37.

Smart, G.C. and K.B. Nguyen. 1991. Sting and awl nematodes. Pp. 627-668 in W.R. Nickle ed., Manual of agricultural nematology. Marcel Dekker Inc., NY. 